THURSDAY, MARCH 4, 1875

SIR CHARLES LYELL, BART., F.R.S.

BORN NOV. 14, 1797, DIED FEB. 22, 1875.

I YELL'S life was uneventful. Great changes in L thought, great scientific discoveries, are not called events. Yet, as might have been expected in the case of a man so active, so famous, so far travelled, his life was full of incident, and groups of incidents lead to or make up events. We are indeed in the habit of looking upon Sir Charles Lyell as representing an idea, a theory, a principle -and rightly so. We cannot say exactly that he originated a new method of investigation, but by the use of the right methods, and in the determination to follow fairly each established fact to its logical consequences, he has taught us the laws which have governed the changes of which we can observe the results in the crust of the earth.

We hear of him as a boy making a collection of insects in the New Forest, to which his father removed soon after he was born. At Oxford we find him studying under Buckland. When called to the bar we hear of him on circuit, but already known as a student of nature; for the story goes that he was often missed, and in reply to the question "Where's Lyell?" the answer was, "Oh! he's sure to be somewhere at the boitom of a well, seeking for truth."

The list of his various papers shows how much original work he did in the earlier part of his career: on the older and newer deposits of his native county, Forfarshire; on various beds in Hampshire; the results of observations as to earth movements and other phenomena in Scandinavia; on denudation and volcanoes in the Auvergne; many papers on the Tertiary deposits at home and abroad, and many on various parts of America. Sixteen years ago he published an elaborate memoir on Mount Etna ; but latterly the result of his work has appeared in his larger books instead of in separate papers, and it is wonderful how far he was able to carry out his determination to verify on the ground all the observations upon which any important reasoning was founded.

No mind more quick to realise the bearing of the new facts continually being brought before it; no judgment more sound to decide whether the evidence was as yet sufficient. Hence, as work after work and edition after edition came out, the geological world turned anxiously to read his judgment on the vexed questions of the day, knowing that no prejudice would prevent his reversing his own former decision if new light had been thrown upon the subject. Doubtful inferences, which depended upon long inductions and incomplete evidence, were always given with such a clear statement of the sources of error still remaining, that many brilliant but too hasty generalisers complained of his tardy acceptance of their ingenious theories; but the public benefited by his caution and care.

There were many great workers and grand reasoners in the field of geological research when Lyell began his course. But his work did not clash with theirs. The chief of them were collecting evidence among the older rocks; Lyell's work was at first among the newer and, as we have seen, even among living forms of life. He at

YOL. XI.-No. 279 first watched active or quite recent volcanoes, while others were searching among the older records of the rocks what really were the facts that had to be interpreted.

For the general question, most of those who had got beyond the Wernerian theory were contented to adopt the views of Hutton, with more or less stress laid upon the periodic catastrophes to destroy the old order of things and to bring new land surfaces within reach of the agencies which Hutton held would then gradually mould and carve them into the varying outlines of hill and valley.

But Lyell's line of investigation soon taught him that there were forces in action sufficient not only to chisel and carve the rocks when thrown up by unexplained convulsions, but that this successive bringing of portions of the earth's crust within reach of the graving tool was also part of the ordinary operations of nature.

This was, in fact, the true theory of evolution applied fully to the crust of the earth, and this paved the way for a rational explanation of the origin of species by Darwin, as the continuity of life is not consistent with the Huttonian theory of periodic interruptions of universal extent. Lyell pointed out that it was a matter of observation that variations occurred--variations of level, variations of texture, of hardness, or solubility - that a process of natural selection determined which should stand and which perish. He was at least as successful as the naturalist in giving a satisfactory reason for the occurrence of many of the variations by reference to observed surroundings and known laws. His views commended themselves to the judgment of thinking men, and Cuvier's "Theory of the Earth" was never repreduced in England after the appearance of Lyell's "Principles" in 1829-30. He steadily opposed the views of Lamarck, who explained the origin of species chiefly by some not very clearly defined adaptability in organic nature which enabled it to develop from time to time such varieties of structure as the changes of external circumstances required; much-used organs were sirengthened and developed ; unused organs were reduced to a rudimentary state. Lamarck's theory was the suggestion of a method by which results such as those observed might have been produced, but he did not show that it was one of the ordinary operations of nature to produce such results in that way. Therefore, the evidence brought forward by Lamarck being faulty, Lyell denied his conclusion, and opposed Lamarck's view as to the continuity of life. When, however, Darwin applied to natural history the methods which Lyell had long used to explain the phenomena of the crust of the earth, and again brought forward the theory of continuity of life, but explained it by variation and natural selection, Lyell accepted the conclusion because now founded on sound reasoning.

Darwin's theory of the evolution of life by the survival of the fittest holds, though we might possibly have to limit our application of it. Lamarck's notion of the development of new forms by dependent modification is not supported by sufficient direct evidence, even when we allow the continuity of life.

Lyell's claim to fame lies in this, that he organised the whole method of inquiry into the history of the formation of the crust of the earth, and established on a sound 
footing the true principles of geological science; his theory being, that by the uniform action of forces such as are now in operation, the visible crust of the earth has been evolved from previous states.

Lyell was not only a keen investigator of natural phenomena; he was also a shrewd observer of human nature, and his four interesting volumes of travel in America are full of clever criticism and sagacious forecasts. His mind, always fresh and open to new impressions, by sympathy drew towards it and quickened the enthusiasm of all who studied nature. Had he done nothing himself, he would have helped science on by the warmth with which he hailed each new discovery. How many a young geologist has been braced up for new efforts by the encouraging words he heard from Sir Charles, and how many a one has felt exaggeration checked and the faculty of seeing things as they are strengthened by a conversation with that keen sifter of the true from the false !

Though by nature most sociable and genial, yet Sir Charles often withdrew from society where the object of his life, the pursuit of science, was not promoted; but when anything interesting turned up he always tried to share his pleasure with all around. Many of us will remember the cheerful and hearty "Look here"-" Have you shown it to so and so?"..." Capital, capital."

The little wayside flower, and, from early happy associations, still more, the passing butterfly, for the moment seemed to engross his every thought. But the grandeur of the sea impressed him most; he never tired of wandering along the shore, now speaking of the great problems of earth's history, now of the little weed the wave left at his feet. His mind was like the lens that gathers the great sun into a speck and also magnifies the little grain we could not see before. He loved all nature, great and small.

Much we owe to Leonard Horner, himself a good geologist, for having inspired the young Charles Lyell. In after years, when already well known, Charles Lyell chose as his wife the eldest daughter of his teacher and friend. Many have felt the charm of her presencemany have felt the influence of the soul that shone out in her face; but few know how much science directly owes to her. As the companion of his life, sharing his labour, thinking his success her own, Sir Charles had an accomplished linguist who braved with him the dangers and difficulties of travel, no matter how rough ; the everready prompter when memory failed, the constant adviser in all cases of difficulty. Had she not been part of him she would herself have been better known to fame. The word of encouragement that he wished to give lost none of its warmth when conveyed by her; the welcome to fellow-workers of foreign lands had a grace added when offered through her. She was taken from him when the long shadows began to cross his path; but it was not then he needed her most. When in the vigour of unimpaired strength he struggled amongst the foremost in the fight for truth, then she stood by and handed him his spear or threw forward his shield. He had not her hand to smooth his pillow at the last, but the loving wife was spared the pain of seeing him die.

It doubtless occurred to many a one among the crowd who saw him laid to rest among the great in thought and action, that he might have been eminent in many a line besides that he chose.

His was a well-balanced judicial mind, which weighed carefully all brought before it. A large type of intellecttoo rare not to be missed. But it was well that circumstances did not combine to keep the young laird on his paternal lands among the hills of Forfarshire: it was well for science that he was induced to prefer the quieter study of nature to the subtle bandying of words or the excitement of forensic strife. Failing health had for some time removed him from debates. Still to the last his interest in all that was going on in the scientific world never failed, and nothing pleased him more than an account of the last discussion at the Geological Society, or of any new work done. As a man of science his place cannot be easily filled; while many have lost a kind, good friend.

\section{THE "BESSEMER"}

THIS novel steamer, upon the construction of which 1 so much care and ingenuity have been expended, is expected to leave Hull for the Thames this week, and shortly will proceed upon her service between Dover and Calais. By experiments recently made at Hull, the power of the apparatus to put the ponderous saloon in motion alternately in opposite directions, has been fully established. It will no doubt be interesting to our readers if we place before them the following observations connected with the design of this vessel.

The chief objects of her designers, Mr. Bessemer and Mr. Reed, were-

1. To reduce the discomfort of the journey to a minimum.

2. To make her very swift, so that the time spent on the sea by her passengers should be as short as possible.

3. To ensure great steadiness among waves, both as to rolling and pitching.

Finally, to provide her with everything that can contribute to the comfort and convenience of the passengers.

All these points were carefully worked out and considered in connection with the limit imposed on her draught of water by the shallow harbour of Calais.

The Bessenter is a double-ended vessel, propelled by four large paddle wheels, two on each side. Each end for a length of about $48 \mathrm{ft}$. is kept low for the purpose of reducing the motions produced by the action of the wind and of the sea, while the middle portion (about $254 \mathrm{ft}$.) of her length is built sufficiently high to enable her to steam at a high speed against the worst seas she will meet. A rudder is fitted at each end with efficient means for locking, so that the Bessemer will be able to steam. in either direction, and will not require to be turned round in harbour, and each rudder is worked by means of Messrs. Brown's patent hydraulic steering gear.

Her great peculiarity, however, is that she contains a large saloon $70 \mathrm{ft}$. long, designed by Mr. Bessemer, suspended in the middle of the ship in such a manner that it can be moved about a longitudinal axis parallel to the keel. The motion of this saloon, which would be set up if left free to move, when the ship rolled, will be governed by an hydraulic apparatus (the invention of Mr. Bessemer), 